Başvuru Tarihi: 21.02.2017 Received Date: 31.07.2017

Yayına Kabul Tarihi: 27.05.2017 Accepted Date: 27.05.2017

Yayınlanma Tarihi: 31.07.2017 Published Date: 31.07.2017
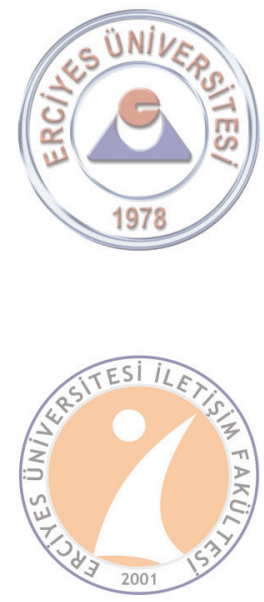

akademia 
ISSN:1308-3198

Erciyes İletişim Dergisi akademia 2017

Cilt (Volume): 5, Say1 (Number): 2, (210-226)
Fuat USTAKARA (Doç. Dr.)

Gaziantep Üniversitesi İletişim Fakültesi

fuatustakara@gmail.com

Emre BURHAN

Gaziantep Üniversitesi S.B.E. Yük. Lis. Öğrencisi

emreburhan@hotmail.com

\title{
TOPLUMSAL ILETIŞIIM KURUMU OLARAK KAHVEHANELERE DAİR BİR ARAŞTIRMA: GAZİANTEP ÖRNEĞİ
}

\section{$\ddot{\mathbf{O z}}$}

Kahvehaneler, 16. yüzyıldan günümüze değin, Türk toplum hayatının önemli sosyal iletişim mekânları olarak kabul edilmektedir. Kahvehaneler, tarihsel süreç içerisinde önemli tartışmaların yapıldığı, siyasal eleştirilerin getirildiği mekânlar olarak dikkat çekmektedir. Bu çalışma, sosyo-kültürel açıdan önemli olarak kabul edilen kahvehanelerin iletişim yönünden özelliklerini açığa çıkarmayı amaçlamaktadır. Gaziantep örneğindeki kahvehanelerde yapılan araştırma sonuçlarına göre, bireyler kahvehanede rahatladıklarını hissetmekte; kahvehanelerdeki sohbet ortamı toplumsal gündem konularına yönelik kanaatleri etkilemektedir. Kahvehanelerde siyaset ve gündem öne çıkmakta; kahvehanelerdeki tartışmalar eleştirel bir nitelik taşıyabilmektedir. Buna göre, kahvehanelerin kamusal iletişim mekânları olduğu düşünülebilir.

Anahtar Kelimeler: Kahvehane, Sosyal Etkileşim, Kamusallık, Kamusal Alan.

\section{A RESEARCH OF COFFEEHOUSES AS THE SOCIAL COMMUNICATION INSTITUTIONS: THE EXAMPLE OF GAZİANTEP}

\begin{abstract}
We notice that coffeehouses are important social communication places of Turkish social life from $16^{\text {th }}$ century to nowadays. People have made important discussions, and brought politic criticism at coffeehouses in the historical process. The study aims to disclose communicative features of coffeehouses which are accepted very important places in terms of socio-cultural structure. According to data of the example of Gaziantep coffeehouses, individuals feel comforted in coffeehouses, and also talk environment of coffeehouses influence the thoughts about social agenda topics. In coffeehouses, politics and agenda become prominent, and the discussion at coffeehouses may have a critical characteristic. Accordingly, we conclude that coffeehouses are public communication environments.
\end{abstract}

Keywords: Coffeehouse, Social Interaction, Publicity, Public Sphere. 


\section{Giriş}

Kahvehane, Türk toplum hayatının önemli bir gerçeğidir. Bir sosyal mekân olarak kahvehaneye adını veren kahve, Türk kültürünün ayrılmaz bir parçası olarak kabul edilmektedir. Bunun göstergeleri olarak, bir fincan kahvenin kırk yıl hatırının olduğu, görücüye çıkıldığında kahvenin ikram edilmesi şeklinde karşılık bulduğu anlatılabilir.

"Kahvehane" sözcüğü, isminden de anlaşılacağı üzere, Türkçede kahve içilen toplu yerlere verilen addır. Tarihsel süreç açısından ilk kahvehanelerin nerede yer aldığına bakıldığında ise 1511'de Mekke'de, daha sonra Kahire'de vücut bulduğu görülmektedir (Hattox, 1998, 12). İstanbul'da ise ilk kahvehanelerin 1553 'te açıldığ 1 ve halkın hızlı bir şekilde bu kültürel ortamı kanıksadığı bilinmektedir (Hattox, 1998, 24). Sosyalleşme açısından kahvehanelerin Türk toplum yaşantısında önemli bir yer tuttuğu su götürmez bir gerçektir.

Türk toplumunda kahvehane kültürünün, aslında 1553’ten önce de yer aldığı bilinmektedir. Kahvehane kültürünün Osmanlı'da görülmesi beraberinde bu mekânlara dönük bir hiyerarşinin şekillenmesine de neden olmaktadır. İlk etapta kahve tüketenler üst sınıftan olduğu için, başlangıçta halk arasında yayılmamıştır. Kahvenin halk tarafından sevilmesiyle birlikte kahvehaneler yaygınlaşmıştır. Kahvehaneler, bir süre sonra halk için boş vakitlerini geçirecek, herkese açık mekânlar haline gelmiştir.

Kahvehane ile eşanlamlı olarak kullanılan "kıraathane" sözcüğü, kahvehanelerin köken olarak okuma işlevinin gerçekleştiği toplumsal mekânlar olduğu ve zamanla bu işlevini yitirerek dönüşüm geçirdiği düşüncesini uyandırmaktadır. Bu noktada kahvehanelerin tarihsel süreçte nasıl bir dönüşüme uğradığı önemli bir detay olarak ortaya çıkmaktadır. Bu gerçeklik, konuya bağlı olarak çalıșmanın önemini teșkil etmektedir. Bunun yanı sıra, çalıșmanın araștırma bölümünde, yöntem olarak belirlenen anket uygulamasıyla günümüz toplumunun kahvehanelere yönelik bakış açısı analiz edilmeye çabalanmaktadır.

$\mathrm{Bu}$ çalı̧̧ma, kahvehanelerin sosyal mekânlar olarak Türk toplumu içerisindeki iletişim işlevlerini anlamaya yönelik bir araştırmadır. Çalışmanın birinci bölümünde, kahveye ilişkin genel bir bilgilendirme yapılmıştır. İkinci bölümde, kahvehanelerin tarihsel süreçteki gelişimi aktarılmış; böylece sosyal işlevlerini anlamaya dönük bir açılım getirilmeye çabalanmıştır. Üçüncü bölüm, kahvehane olgusunun sosyal işlevine bağlı olarak kamusallık özelliğini açıklamaya girişmektedir. Dördüncü bölümde, kahvehanelerin Türk toplum kültürünün sosyal dokuları olarak iletişimsel fonksiyonları bir bilimsel araştırma metodu ile araştırılmaktadır. Çalışma, iletişim sosyolojisi açısından araştırmacılar için önemli veriler içermesi yönüyle literatüre katkı sağlamaktadır.

\section{Kahve}

Kahvehaneye geçmeden önce, ona adını veren "kahve" sözcüğüne kısaca değinmekte yarar olduğu görülmektedir. Kahve, Arabistan Yarımadası kökenli olan Rubiaceae ailesinden olan Coffea cinsi bir ağacın meyvesinin çekirdeğidir (Koz, 2011, 13). İsminin kökeni tartışmalarından kayda değer olanlardan biri, ismin Afrika kökenli olduğu yönündedir. İsmini, ilk çıkış noktası olarak gösterilen Etiyopya'nın Kaffa Bölgesi'nden aldığı söylenmektedir (Hattox, 1998, 16). Tartışmalardan bir diğeri ise, ismin Arapça kökenli olduğudur. Arapçada şarap manasına gelen "kahva" kelimesinden türetildiği dile getirilmektedir (Aydın, 2011, 81). İçecek olarak kullanılmadan önce zindelik verdiğinden dolayı çiğnenmiş olabileceği aktarılmaktadır (Standage, 2016, 137).

Kahvehanenin gelişimi öncesinde, bu sosyal mekâna adını veren kahvenin ortaya çıkışına ilişkin bir ön bilgi verilecek olduğunda, şu bilgilere erişilmektedir. Kahvenin vatanı Etiyopya olmakla birlikte, buradan Yemen'e getirilmiştir (Heise, 2001, 13). Önemli bir detay olarak, 14. yüzyılda içecek halini aldığı yer Yemen'dir (Koz, 2001, 17). İstanbul'da açılan ilk kahvehaneye gelmeden önce dahi camii avlusunda kahve içip, muhabbet eden insanlar ilk kahve yasaklarıyla karşılamışlardır. 1510 tarihine gelindiğinde, kahve Mekke ve Medine'de iyice bilinir hale 
gelmişti ve tarihte bilinen ilk kahve yasağı Mekke'de 1511 yılında Hayır Beğ (Mekke Emiri) tarafından konulmuştur (Hattox, 1998, 12). Daha sonra 1532 ve 1533 'te Kahire'de kahve yasakları uygulanmıştır (Tez, 2015, 224). Kahire'nin fakihlerinden Ahmet Bin Abdullah Sunbati'nin fetvası üzerine konulan kahve yasağı kalıcı olamamıştır (Demiray, 2011, 68). Kahvenin Kahire'den hac kervanları ile Suriye'ye geçmesi yaklaşık on yıl sürmüştür; buradan ise İstanbul'a ulaşmıştır (Hattox, 1998, 24). Birsel'e göre $(2014,11)$, kahvenin Yemen'den sonra Suriye, Mısır, İran ve Hindistan'a doğru yayılması bir asır sürmüştür. Bu bilgilerden çıkarılacak sonuç, kahve içeceğinin yasaklar ile anılmasıdır. Farklı toplumlarda da toplumun farklı sosyal tabakalarından insanların bir araya gelip, iktidar için tehdit oluşturabilecek fikirler etrafında toplanmaları, yasakların en önemli sebebi olarak görülmektedir. Toplumlar farklı, ancak iktidarların kendilerini koruma şekli benzerdir.

\section{Kahvehanelerin Tarihsel Süreçteki Gelişimi}

Fikirlerin paylaşılması ve yayılabilmesi için bu fikirlerin tartış1labileceği mekânlara ihtiyaç vardır. Osmanlı'da bu kamusal mekânların oluşumları ilk kahvehanelerden başlayarak devam etmektedirler (Öztürk, 2010, 332). Bu açıdan, kahvehane, Osmanlı döneminde bir sosyal iletişim kurumu olarak oldukça önemli bir işleve sahip olmuştur.

Kahvenin Osmanlı toplumuna girişi, sosyal kurum olarak kahvehaneyi de bu topraklara getirmiştir. Heise (2001, 21), kahvenin İstanbul'da ilk kez 1517 y1lında içildiğini aktarmaktadır. Kanuni Sultan Süleyman döneminde (1520-1566), Habeşistan Valisi Özdemir Paşa tarafindan getirildiği bilgisi verilmektedir (Ulusoy, 2011, 161). Lewis $(1975,154), 1554-1555$ yılına kadar İstanbul'da kahvehane olmadığını ve daha sonra Halepli Hakim (Hakem) ve Şamlı Şems adında kişilerin gelip İstanbul Tahtakale'de birer kahvehane açtığını belirtmektedir. Hakem ve Şems, kahvenin İstanbul' da yaygınlaşmasını sağlayarak büyük bir servet elde etmişlerdir (Hattox, 1998, 64). Kurulan mahalle tipi kahveleri yeniçeri, tulumbacı ve semai kahveleri izlemiştir (Nazır, 2011, 304). 16. yüzyılda kahve içmenin yaygınlaşmasıyla birlikte kent, köy ve kasabalarda toplum yaşamını etkileyecek, kamusal bir mekân olan kahvehane doğmuştur (Hattox, 1998, 65). Kahve, daha sonra Babıali’nin tuğrasını ve sancağını izleyerek Batıya doğru yayılmıştır (Heise, 2001, 21).

Kahvenin yasaklanması gerçekliği gibi, kahvehanelerin yasaklanması da dikkat çekmektedir. Bu yasakları aktaran bilgilere yer vermek gerekir. Kahve ve kahvehanelerin Anadolu topraklarına gelişi, yaklaşı 500 yı öncesine dayanmaktadır (Ürer, 2010, 11). İlk kahve yasakları her ne kadar helâl-haram tartışmaları arasında başlamış olsa da, asıl sebep toplumun farklı sınıflarında insanların bir araya gelerek fikir alışverişinde bulunmuş olmalarıydı (Deniş, 2011, 6). Yaşar'a göre $(2010,1405)$, iktidarın asıl hedefi içecek olan kahveden ziyade kahvehanelerdi.

Kahvehane yasaklarının tarihsel geçmişinin eskiye dayandığı kaynaklardaki bilgilerden açığa çıkmaktadır. İlk kahve yasağının, Kanuni Sultan Süleyman döneminde (1520-1566), Şeyhülislam Ebusuud Efendi'nin fetvası ile meydana geldiği vurgulanmaktadır (Demiray, 2011, 69). Birsel $(2014,13)$, kömürleşinceye kadar kavrulan şeylerin günah olduğu fetvasıly, kahve çuvallarının delinip denize döküldügünü aktarır. Ancak bu yasağa padişah tarafından onay gelmediğinden ötürü halk üzerinde bir etkisinin olmadığını dile getirir. Öte yandan bazı kaynaklar böyle bir fetvanın olup olmadığı konusunda belirsizlik olduğundan söz etmektedir (Saraçgil, 1999, 30; akt. Şahbaz, 2007, 48; Yaşar, 2010, 1403). İlk kahve yasağının hangi padişah döneminde olduğuna ilişkin farklı kaynaklar farklı dönemlerden bahsetmektedir. Ancak bu dönem yapılan kahve ve kahvehane yasağı halk ve kahve tüccarlarının tepkisiyle karşılaşınca pek uzun ömürlü olmamıştır (Demiray, 2011, 69).

Koçu (2003, 39), “Tarihimizde Garip Vakalar" adlı kitabında ilk kahve ve kahvehane yasağının III. Murat döneminde (1574-1595) olduğuna değinmektedir. Yasakları delmeye çalışan ve bu işten kâr sağlayan kahveciler, tenha yerlerde kahveciliği sürdürmeye devam etmişlerdir. $\mathrm{Bu}$ işi sürdürebilmek için ise dönemin kolluk kuvvetlerine kendilerini görmezlikten gelmeleri için rüşvet vermişlerdir (Göktaş, 1999, 74). Bu tenhadaki kahvehaneler "koltuk kahvesi" olarak isimlendirilmiştir (Birsel, 2014, 13). Bu yasağın sebebi ise, kahvehanelerde devlet işlerinin 
konuşulması, devlet adamlarının eleştirilmesi sonucu ulemanın çoğunluğunun kahve karşıtı tutum sergilemesiydi. Ancak 1517 'den itibaren kahvenin ulema dahil yöneticilerin sarayda kahve içiyor olmaları, yasağın asıl nedeninin kahve olmadığını ortaya koymaktadır (Öztürk, 2010, 334). Kahve yasağının akabinde Şeyhülislam Bostanzade Mehmet Efendi (1539-1605), yeni fetva ile kahvenin mekruh görüldüğünü açıklamıştır (Göktaş, 1999, 75). Bu yeni fetva üzerine 1592'de III. Murat kahve yasağını kaldırır ve hızlı bir şekilde kahveler yeniden açılmaya başlar (Birsel, 2014, 14).

III. Mehmet döneminde (1595-1603), kahvelerdeki yönetime karşı olan tutumun artması ve toplumsal düzeni bozucu olarak görülmesi yeni bir kahve yasağına sebebiyet vermiştir (Şahbaz, 2007, 49). Bu yasak gösteriyor ki, asıl tehlike kahve içmek değil, kahvehanelerde oluşan yönetim karşıtı söylemlerdir. Öztürk'ün de belirttiği gibi, iktidar denetiminden uzakta kalan mekânlarda paylaşılan fikirler iktidarlar için tehlike oluştururlar (Öztürk, 2010, 332).

I. Ahmet döneminde (1603-1617), tütünün İngiliz gemiciler tarafından İstanbul'a getirilmesi, kahvehanelerin daha fazla dolmasını sağlamıştır (Koçu, 2003, 50). Naima, tütünün 1606 yılında Frenkler tarafından getirildiğini dile getirmiştir (Birsel, 2014, 15). Peçevi’ye göre ise 1600 yılında (III. Mehmet dönemi) gelmiştir ve şifacı etkisi olduğunu öne sürerek pazarladıkları tütünün yayılması çok uzun sürmemiştir (Göktaş, 1999, 75-76). Kahvehanelere bu dönemde kayıkçı, tersane kalyoncu, yeniçeri, hamal, hamam uşağı, fırın uşağı gibi bekâr ayak takımının çokça gelmesi beyefendilerin, kibar kimselerin büyük kahvehanelerden çekilerek mahalle kahvehanelerine gitmelerine neden olmuştur (Koçu, 2003, 40). Derviş Paşa ile Nasuh Paşa'nın kahvehaneye ve tütüne getirdikleri yasaklar, tepkiler dolayısı ile çok uzun ömürlü olamamıştır (Göktaş, 1999, 76). Buradaki örneklerden de açıkça görülmektedir ki, kahvehanelerin sosyal mekânlar olarak tüm yeniliklere açık yapısı, bu mekânların yasaklanmalarına da zemin hazırlamaktadır.

Kahvehanelerin kötü ün edinmesindeki sebeplere de kaynaklardaki bilgilerden rastlanmaktadır. Yeniçeri Ocağı'nı kaldırmak isteyen Genç Osman'ın(1618-1622) katledilmesinin ardından, kahvehaneler isyancıların bir araya geldikleri yerler olmuşlardır. Naima, IV. Murat döneminde (1623-1640), 1633 yılına gelindiğinde büyük İstanbul yangını bahanesiyle, tütün ve kahveye yasak getirildiğini söyler (Birsel, 2014, 14). Göktaş $(1999,76)$ ise, bu yasağın asıl amacının ahlaksızları terbiye etmek ve halkı korkutmak olduğunu aktarır. Koçu'nun deyimiyle $(2003,40)$, "kahvehaneler tütün ateşine yandı" ve çok şiddetli bir kahve yasağı çıktı. Yasak o kadar sert oldu ki, Edirne'de kahve açıldığ 1 haberi üzerine IV. Murat, kahve işletenleri astırdı (Koçu, 2003, 40). Kapanan kahveler bekâr odalarına dönüştürüldü (Birsel, 2014, 15). Yasak sebebi, kahvede yönetimle alakalı olan dedikodulardır (Ortaylı, 1987, 152; akt. Kazancı, 2006, 14). Heise $(2001,22)$, bu yasağın 17 . yüzyıl minyatürlerinde kahvehane motifinin eksikliğinde ciddi bir etkisinin olabileceğinden söz eder.

I. İbrahim'in hüküm sürdüğ̈ dönemde (1640-1648) ise daha çok tütün yasağına ağırlık verilmesiyle kahve yasağı iyice ortadan kalkar (Göktaş, 1999, 76). Kahvehaneler dolup taşmaya başlar. O dönem vezirler dahi kahvehane yaptırıp kiraya vererek buralardan gelir elde ederler (Birsel, 2014, 17).

Belli dönemlerde yasaklanan kahveler II. Mahmut dönemine (1808-1839) kadar yasaklanmamıştır. Yasağın nedeni ise halkı kısıtlamak değil, kanlı bir mücadele ile kaldırılan Yeniçeri Ocağı'nın destekçilerinin kahvehanelerde buluşup fitne çıkarmasını ve toplantı yapmasını engellemektir (Koçu, 2003, 40). 1826'da ocağın kaldırılmasının ardından yeniçerilere ait olan Boğaziçi Kıyılarındaki kahveleri yıkar (Birsel, 2014, 18). Ocak kaldırıldıktan sonra kahvehanelerin kapatılması, iktidar için risk oluşturduklarını göstermektedir (Ediz, 2008, 180). $\mathrm{Bu}$ yasak çok uzun sürmeden kalkar ve kahveler yavaş yavaş açılmaya başlar (Koçu, 2003, 40). Bir daha toplu olarak kahve yasakları olmamıştır; ancak düzeni bozucu nitelikte sayılan kahvehaneler zaman zaman tek olarak yıkılmışlardır (Birsel, 2014, 17).

Tüm bu yasaklara bakıldığında, ortaya siyasi kontrol sebeplerinden dolayı yapılan yasaklar çıkmaktadır. Genellikle bu yasakların sağlam dayanakları olması adına ilk etapta dini temelli 
tartışmalar gösterilmiştir. Yine de bu yasaklar insanların bir araya gelmesini engelleyememiş; zaman zaman yavaşlatmış ve hatta durdurmuş olsa dahi, insanların iletişim ihtiyacı yasakları bir şekilde delmeyi başarmış gibi görünmektedir.

\section{Tartışmalı Yönleriyle Kamusal İletişim Mekânları Olarak Kahvehaneler}

Kahvehaneler farklı demografik özelliklerden ve farklı görüşlere sahip olan insanların bir araya gelebileceği bir mekân olma özelliğini taşımaktadır (Öztürk, 2005, 102). Tarihsel süreç boyunca çok tartışılmış olmakla birlikte, kahvehaneler önemli sosyal iletişim merkezleri olarak işlev görmüşlerdir. Kahvehanelerin pek çok sosyal, entelektüel, psikolojik, siyasal, kültürel, dinsel vs. işlevlerinden söz edilebilir (Okumuş, 2013, 122). Bununla bağlantılı olarak, insanlar bu mekânlara eğlenmek, günlük yaşamın stresini gidermek ve sohbet etmek amaciyla gitmektedirler (Yağbasan ve Ustakara, 2008, 258).

Kahvehanelerin toplumsal işlevselliğine yönelik bilgiler eşliğinde nasıl bir iletişim mekanizmasına sahip oldukları anlaşılabilir. Kahvehaneler ortaya çıkmadan önce erkekler günlük yaşam içerisinde ev, camii, dükkân arasında mekik dokumaktadır. Bu kültürün insanların hayatına girmesiyle sosyalleşebilmişlerdir (Tunç, 2014, 1). 16. yüzyıl kentli insanın kahvehaneye gösterdiği aşırı ilginin sebebi, bir nevi evden dışarı çıkmak için sosyalleşebilecek bir mazeretinin olmasıdır (Hattox, 1998, 83). Kahvehaneler, gayrimüslimlerin uğrak yeri olan meyhanelere gidemeyen Müslümanlar için fevkalade güzel mekânlar olmuşlardır. Vakit geçirmek, oyun oynamak, sohbet etmek amacıyla gidilen bu mekânlar, bir Müslümanın itibarını zedelemediği için insanlar tarafından çok hızlı bir şekilde benimsenmiştir (Heise, 2001, 21). Buna göre, kahvehanelerin Osmanlı toplumunda erkeklerin ideal buluşma mekânları oldukları söylenebilir.

Kahvehanelerin ilk ortaya çıkışında, sosyal hayat içerisinde önemli roller üstlendiği aktarılmaktadır. Özdemir Nutku'ya göre (1976, 74; akt. Göktaş, 1999, 70), kahvehaneler ilk zamanlarında kıraathane adı verilen okuma evleri gibi gazete, dergi, kitap okunan, çeşitli oyunlar oynanan ve meddahların hikâye anlattığ 1 yerlerdir. Edebi ve önemli siyasal tartışmaların yapıldığı bu mekânlar, zaman içinde değişime uğramışlardır (Yağbasan ve Ustakara, 2008, 234).

Kahvehaneler, iktidar adına düzeni bozucu ara form niteliğindeydiler. Daha önceleri olmamasına rağmen yöneten ve yönetilenin bir araya gelebileceği mekânlar olma özelliğine sahip oldular (Öztürk, 2005, 103). Berkes $(2012,44)$, Osmanlı Dönemi'nde ilk defa siyasi dedikoduların yapıldığı yerin kahvehaneler olduğunu dile getirmektedir. Bu gerçeklikle bağlantılı olarak, kahvehaneleri hedef gösteren nedenlerden biri, siyasal söylentinin bu mekânlarda yoğunlaşması olarak gösterilmektedir (Öztürk, 2006, 65). Bilhassa büyük İstanbul kahvehaneleri, toplumun her kesiminden insanı ağırlamakta ve buralarda halkın devlet ile ilgili görüş ve fikirleri açığa çıkmaktaydı (Hattox, 1998, 84-90). Tarihsel geçmiş dikkate alındığında, özellikle İstanbul kahvehanelerinin önemli sosyal işlevler üstlendiği anlaşılmaktadır.

Kahvehanelerin bu eleştirel aleni yapısının bir kamusallığa işaret ettiği, Habermas'ın Kamusallığın Yapısal Dönüşümü adlı eseri ölçüt olarak alındığında rahatlıkla görülebilmektedir. Habermas'a göre $(2009,189)$, düșünce üreten kamusal topluluğun kanaati, kamusal meseleler üzerindeki özel düşünceden ve kamusal tartışmadan doğmaktadır. Habermas'ın iletișimsel kamu alanı modeline baktığımızda, kamu alanını burjuvazinin üstünlük kurarak kendini devam ettirmek için kullanmak yerine diğer insanlarla ortak bir düşünce, söylem geliştirerek toplumsal kurallar ve alınan politik kararlardan etkilenenlere söz hakkı tanıması olarak yorumlanabilir (Ünüvar, 2006, 240; akt. Deniş, 2011, 3). Osmanlı toplumunda otoriteyi eleştirici bu sohbetler, içecek olan kahveden ziyade mekânlara yönelik yasaklara sebep olmuşlardır (Çağlayan, 2001, 9; akt. Şahbaz, 2007, 49). Devlet sırları, saray çalışanları ve padişah yakınları tarafından kahvehanelerde dile getirilmiştir (Tutal, 2014, 157).

Kahvehanelerdeki toplumsal çeşitlilik, halkın siyaset ve edebiyat hakkında bilgi edinmesini sağlamıştır. Konuşulan siyasi sohbetler, daha önceleri bilgi sahibi olmayan halkı bilinçlendirmeye başlamıştır (Deniş, 2011, 6). Buradan kahvehanelerin bir kanaat oluşturma işlevselliğine çıkarım 
yapmak mümkündür. “Ortaylı da (1983) geleneksel toplumlarda kamuoyunun oluştuğu çeşitli yerlerin olduğunu bunların başında da hamamlar, tekke ve kahvehane gibi yerlerin olduğunu ifade etmektedir" (akt. Ulusoy, 2011, 89).

Osmanlı toplumunda önemli kanaat önderlerinin kahvehanelerde bulunduğuna kaynaklar yer vermektedir. Bu mekânlara geçmişte okuma yazma bilen aydın kimseler gelir; siyaset, din, gündelik vb. konular üzerinde konuşur; diğer insanlar dinleyici olarak bu sohbetlerde bulunarak bilgi sahibi olmaktadır (Sami, 2010, 167). Edebiyatçılar o kadar sık gelip sohbet etmektedirler ki, Hasan Ali Yücel kahvehaneleri akademi olarak adlandırılmaktadır (Birsel, 2014, 233).

Her zaman halk arasındaki sohbetler bilgilendirici nitelikte değil; bunun yanı sıra mahalle dedikoduları ve boş sohbetler de yapılırmış. Hattox $(1998,88)$, konuşulan konu ne olursa olsun sohbet sanatı için kahvehaneden daha uygun bir mekân düşünülemeyeceğinden bahsetmektedir. Kahvehaneler, edebiyatta da kendine sıkça yer bulmuştur (Yağbasan ve Ustakara, 2008, 238). Edebiyatçılar, kahvehanelerde insanlarla fikir alışverişinde bulunmuş ve aynı zamanda insanları gözlemleyerek kendilerine malzeme çıkarmak adına buralardan beslenmişlerdir (Tunç, 2014, 57). Meddahlar, otorite tarafindan alınan kararları halka aktarır ve padişahları eleştirirlermiş (Çetinkanat, 1997, 13; akt. Şahbaz, 2007, 64). Buna göre, kahvehanelerin eleştirel nitelikleri kamusallığa açık oluşlarından kaynaklanmaktadır.

Kahvehanelerin sosyal mekânlar olmaları, kötü amaçlı kullanılmaya açı olmaları anlamına da gelmekte; çeşitli kaynaklarda buna dikkat çekilmektedir. İktidar açısından en riskli mekânlardan biri, yeniçeri kahvehaneleri olarak belirmiştir. Buralar, savaşmak ve hizmet için devşirilen yeniçerilerin buluşma alanları olmuşlardır. Bu buluşmalarda sadece siyasi eleştiriler tartışmalarla kalmamış, iktidar karşıtı eylemler için planların da hazırlıkları yapılmıştır (Öztürk, 2005, 103). Tutal'ın örneği, buna uygun görünmektedir. III. Selim'in tahttan indirilmesiyle sonuçlanan Patrona Halil İsyanı, isyanın liderlerinden olan bir yeniçerinin kahvehanesinde başlaması gibi sıkıntılı ve iktidar karşıtı eylemlere zemin hazırlamıştır (Tutal, 2014, 157). Ayrıca Akdağ da (1995), “1583 yılında Ankaralıların İstanbul'a gönderdikleri bir temsilcinin, otuz yıldır faaliyette bulunan kahvehanelerin iyi niyetle açılmasına rağmen, zamanla amacından uzaklaştığından ve türlü ahlaksızlıkların sergilendiği fesat yuvaları haline geldiğinden yakındığını; Karahisar'dan gönderilen dilekçelerde ise kahvehanelerde çengi oynatıldığının, dedikodu yapıldığının ve neticede batakhaneye dönüştügünün ileri sürüldügünü; bu yüzden bunların 1slahı ya da kapatılması hususunda padişahtan yardım istendiğini ifade etmiştir" (akt. Kuzucu ve Koz, 2015, 57). Kahvehaneler, bu yönleriyle de eleştirilmeye açık mekânlar olmuşlardır.

Baskının kitlesel olarak gerçekleşmesi, geniş okuyucu kitlesine erişimi beraberinde getirmiştir. Böylece kahvehanelerin işlevsel düzeyde okurlara açık konuma gelmesiyle kıraathane adı öne çıkmıştır. Çeşitli kaynaklar, kıraathanelerin işlevlerini açıklamaktadır. 1857 'de ilk kıraathane açılmış, ilk defa müşterileri için gazete ve dergi bulundurmaya başlamıştır (Tunç, 2014, 79). Böylelikle gazete kahvehaneye girdikten sonra kahvehane müdavimi sayısı artmıştır (Çağlayan, 2012, 107). Gazeteler okuma yazma bilmeyenler için yüksek sesle okunur, böylelikle onların da günlük haberleri alması sağlanırdı (Deniş, 2011, 6). Kahvehaneler, bu yönüyle toplumsal iletişim kurumları olarak daha da önemli bir konuma gelmişlerdir. Bunu destekleyen bir açıklamaya göre, "Birinci Dünya Savaşı sırasında İstanbul'da yapılan bir ankete göre, yüz yirmi kişiden kırk altısı yani yaklaşık yarısı kahvehaneye gazete okumak için gittiğini belirtmiştir" (Georgeon, 1999, 71; akt. Çağlayan, 2012, 107). Radyo da tıpk1 gazetede olduğu gibi kahvehanelerde kendine yer bulmuş; insanlar için yeni bir haber alma ve eğlence aracı haline gelmiştir (Çağlayan, 2012, 108). Sosyal mekân olarak kahvehane, çağın getirdiği iletişim araçlarını bünyesine alarak çekiciliğini artırmıştır.

Cumhuriyet döneminde de kahvehanelerin önemli sosyal kurumlar olarak kendini gösterdiği anlaşılmaktadır. Kahvehanelerin sosyal hayatta öneminin göstergeleri, Sait Faik'in Mahalle Kahvesi adlı eserinde okunabilir (Abasıyanık, 2005, 9-13). Ayrıca günümüz edebiyatında Orhan Pamuk, Istanbul -Hatıralar ve Şehir adlı eserinde kendi hatıralarından 
bahsederken kahvehanelere de yer vermiştir (Pamuk, 2013). Kahvehanelerin edebiyatın içerisine girmesi, aslında bu sosyal mekânların toplumsal hafızada önemli bir yere sahip olduğunu göstermektedir. Türk sinemasında, dizilerinde ve yer yer reklamlarda dahi kahvehanelere yer verilmektedir. Kahvehaneler insanları bir arada tutması işlevi göz önünde bulundurularak, senaryolarda önemli bir yere sahip olmaktadır (örneğin, Canım Kardeşim, 1973; Aslan Bacanak, 1977; Yüz Numaralı Adam, 1978; Umudumuz Şaban, 1979; Üç Kâğıtçı 1981; Yedi Bela Hüsnü, 1982; Orta Direk Şaban, 1984; Ekmek Teknesi, 2002; Kardeş Pay1, 2014). Bahsi geçen yapımlar, kahvehanelerin Türk toplum hayatında sosyal iletişim kurumları olarak önemini gözler önüne sermektedir.

"Kahvehane" ile eşanlamlı olarak kullanılan "kıraathane" sözcüğ̈̈, kahvehanelerin köken olarak okuma işlevinin gerçekleştiği toplumsal mekânlar olduğu ve zamanla bu işlevini yitirerek dönüşüm geçirdiği düşüncesini uyandırmaktadır. Sözlük anlamına bakıldığında, temel başvuru kaynağında geçen şekliyle "kahve, çay, ıhlamur, bira, nargile içilen; hafif yiyecekler bulunduran; tavla, domino, bilardo, kâğıt vb. oyunlar oynanan yerler" (Türk Dil Kurumu [TDK], 16 Haziran 2016) olarak tanımlanmıştır.

Kahvehanelerin önemli sosyal işlevlerini açıklayan araştırmalara literatür taramasında rastlanmaktadır. Örneğin, Ulusoy’un çalışmasının sonucuna göre $(2011,168)$, kahvehanelerde güncel konular ve kültürel konularda faaliyetlerin gerçekleştirilmekte oluşu önemli bir durum olarak saptanabilir. Buna ek olarak, Yağbasan ve Ustakara'nın çalışmasında (2008, 248), kahvehanelere insanların daha çok eğlenmek, sohbet etmek ve oyun oynamak amacıyla gittikleri veri göstergeleriyle ortaya konmaktadır. Buradan da sosyal mekânlar olarak kahvehanelerin Türk toplumu için önemli iletişim merkezleri olduğu kanısına varılabilir.

\section{Araştırma}

Çalışmanın dördüncü bölümü, sosyal mekânlar olarak kahvehanelerin iletişimsel özelliklerini tespit etmeye dönük bir alan araştırmasına dayandırılmaktadır. Bu bölüm, içeriğinde problem durumu, araştırmanın amacı ve önemi, araştırmanın yöntemi, veri toplama araçları, verilerin analizi ve bulguların yorumu kesitlerini toplamaktadır.

\subsection{Araştırmanın Problemi}

Tarihsel süreç içerisinde, kahvehanelerin sosyal iletişim mekanizmaları olarak ne kadar önemli bir yer tuttuğu literatür taramasından ortaya çıkmaktadır. Günümüzde kahvehanelere yönelimin ne sıklıkla olduğu, kahvehanelerde hangi konuların ön plana çıkarak konuşulduğu, kahvehane ortamının eleştirel yönünün ne yoğunlukta olduğu konuları araştırılması gereken olgular olarak görünmektedir. Bu çalışmanın problem durumunu, sosyal iletişim kurumları olarak kahvehanelerin sosyal işlevselliklerinin araştırılması oluşturmaktadır.

\subsection{Araştırmanın Amacı ve Önemi}

Kahvehanelerin sosyal iletişimin önemli merkezleri olarak araştırılmasından ortaya çıkacak sonuç, iletişim sosyolojisi açısından önemli veriler içerecektir. Bu araştırmanın amacı, toplumsal iletişim kurumları olarak kahvehanelerin işlevselliğine ilişkin bilgi edinmektir. Sosyal hayattaki önemini kavramak açısından, bireylerin kahvehaneye geliş nedenleri, kahvehanelerde konuşulan konuların hangi alanlarda yoğunlaştığı hususlarında bilgi toplamaya çalışılmaktadır. Araştırma, bu yönüyle iletişim sosyolojisi açısından önemlidir.

\subsection{Araştırmanın Yöntemi}

Araştırma, bir alan araştırması olarak anket uygulamasına dayandırılmaktadır. Kuş'un belirttiği gibi $(2009,44)$, anket uygulamaları kişisel ifadelere dayalı inançlara ya da davranışlara ilişkin araştırma sorularının aktarılması noktasında elverişli bir yöntem olmaktadır. Araştırma sonucunda, kişisel yargıların toplamını ögrenmek açısından anket uygulamasının verileri yol gösterici olacaktır. 
Anket çalışması, Gaziantep kent merkezinde yer alan 11 farklı kahvehaneden 457 katılımcıya uygulanmıştır. Bu kahvehaneler Gaziantep kent merkezinin farklı mevkilerinde yer aldıkları için anket uygulamasında sosyo-demografik açıdan katılımcıların heterojen bir dağılımı olmuştur. Anketin uygulanması sürecinde, katılımcıların gönüllülüğü esas alınmıştır. Anket uygulaması, 2016 yılı Temmuz ayında yapılmış; uygulama, kahvehaneler ile sınırlı tutulmuştur.

\subsection{Veri Toplama Araçları}

Araştırma sürecinde, veri toplama araçları olarak çoğaltılmış anket formları ile kalem, silgi gibi kırtasiye malzemesi kullanılmıştır. Araştırma, verilerin bilgisayar ortamında işlenmesi ile gerçekleştirilmiştir. Araştırma sürecinde; frekans analizi, aritmetik ortalama hesaplaması ve ANOVA analizi gibi istatistik uygulamalarından yararlanılmıştır. Aritmetik ortalamalarda gerçekleşen sorgulamalar beşli likert ölçeğe göre yapılmıştır. Bu kapsamdaki ölçümleme, en düşük düzeyde yer alan "kesinlikle katılmıyorum" seçeneğinden en yüksek düzeyde yer alan "kesinlikle katılıyorum" seçeneğine değin sıralanmıştır.

\subsection{Verilerin Analizi}

Araştırmadaki sosyo-demografik değişkenler; cinsiyet, yaş, medeni durum, meslek, gelir durumu, eğitim durumu ve memleket olmak üzere yedi temel sorgulamadan oluşmaktadır. Buna göre sosyo-demografik özelliklere göre dağılım aşağıdaki gibidir:

a) Cinsiyete göre dağılımda, katılımcıların \%100’ü (457 kişi) erkektir.

b) Katılımcıların yaşa göre dağılımında; \%22,1'i (101 kişi) 26-33 yaş arası, \%20,5'i (94 kişi) 34-41 yaş arası, \%16'sı (73 kişi) 42-49 yaş arası, \%12,9'u (59 kişi) 58-65 yaş arası, \%12,5'i (57 kişi) 50-57 yaş arası, \%11,8'i (54 kişi) 18-25 yaş arası ve \%4,2'si (19 kişi) 66 yaş ve üzeri şeklinde olduğu görülmektedir.

c) Katılımcıların medeni duruma göre dağılımları; \%74,4'ü (340 kişi) evli, \%25,6's1 ise bekâr olarak şekillenmektedir. Evli olan katılımcıların çocuk sayısına göre dağılımında; \%30'unun (102 kişi) iki çocuğu, \%28,2'sinin (96 kişi) üç çocuğu, \%22,7'sinin (77 kişi) dört ve dörtten fazla çocuğu, \%16,2'sinin (55 kişi) bir çocuğu olduğu belirtilmiştir. \%2,9'u (10 kişi) "çocuğum yok" demiştir.

d) Katılımcıların mesleğe göre dağılımında; \%39,2 (179 kişi) esnaf, \%27,6 (126 kişi) işçi, \%17,5 (80 kişi) emekli, \%6,1 (28 kişi) işsiz, \%4 (18 kişi) devlet memuru, \%3,5 (16 kişi) öğrenci, \%0,6 diğer kategorisini işaretlemiştir. Bu soruya cevap vermeyenler \%1,5 (7 kişi) oranı ile sınırlı kalmıştır.

e) Aylık gelir durumuna göre ${ }^{l}$ dağılımda; katılımcıların \%40,9'unun (197 kişi) 1301$2000 \mathrm{TL}$ aras1, \%38,1'inin (174 kişi) 2001-3000 TL arası, \%13,1'inin (60 kişi) 0-1300 TL aras1, \%4,2'sinin (19 kişi) 3001-4000 TL arası, \%1,5'inin (7 kişi) 4001-5000 TL arası ve \%0,4'ünün (2 kişi) 5001 TL ve üzerinde gelire sahip olduğu görülmektedir. Cevapsızların oranı, \%1,8'dir (18 kişi).

f) Katılımcıların eğitim durumuna göre dağılımında; \%66,7'sinin (305 kişi) ilkokul/ ilköğretim düzeyinde eğitim aldığı, \%13,6'sının (62 kişi) lise düzeyinde eğitim aldığ 1 , \%11,6'sının (53 kişi) okuryazar olduğu, \%2,4'ünün (11 kişi) fakülte düzeyinde eğitim aldığ 1 ve \%2'sinin (9 kişi) yüksekokul düzeyinde eğitim aldığı görülmektedir. Bu kategoriye \%3,7 (17 kişi) oranında cevap verilmemiştir.

g) Katılımcıların memleketine göre dağılımında; \%35,2 (161 kişi) Gaziantep, \%11,8 (54 kişi) Kahramanmaraş, \%10,5 (48 kişi) Şanlıurfa, \%10,3 (47 kişi) Kilis, \%8,5 (39 kişi) Adıyaman, \%6,6 (30 kişi) Diyarbakır, \%5 (23 kişi) Mardin, \%3,7 (17 kişi) Malatya, \%3,3 (15 kişi) Adana, \%2 (9 kişi) Hatay, \%0,7 (3 kişi) Osmaniye kökenli olduklarını belirtmişlerdir. "Diğer" kategorisi \%2,4 (11 kişi) ile sınırlıdır.

\footnotetext{
${ }^{1}$ Anket uygulama sürecinde asgari ücret miktarı 1300 TL olarak geçmektedir.
} 
Katılımcıların kahvehaneye temel geliş nedenleri aşağıdaki tablodaki gibi yansımaktadır (bkz. Tablo 1):

Tablo 1. Katılımcıların Kahvehaneye Temel Geliş Nedeni

\begin{tabular}{|l|c|c|l|c|c|}
\hline Geliş Nedeni & $\mathbf{N}$ & $\mathbf{\%}$ & Geliş Nedeni & $\mathbf{N}$ & $\mathbf{\%}$ \\
\hline Oyun oynamak (52, okey, tavla vb.) & 215 & 47,0 & Maç seyretmek & 27 & 5,9 \\
\hline Gazete okumak & 61 & 13,4 & Televizyon izlemek & 9 & 2,0 \\
\hline Sohbet etmek & 48 & 10,5 & Kumar oynamak & 4 & 0,9 \\
\hline Kişisel sorunları unutmak & 40 & 8,8 & Radyo dinlemek & 1 & 0,2 \\
\hline Dedikodu yapmak & 28 & 6,1 & Cevapsız & 2 & 0,4 \\
\hline İșsizlikten dolayı & 22 & 4,8 & Toplam & $\mathbf{4 5 7}$ & $\mathbf{1 0 0 , 0}$ \\
\hline
\end{tabular}

Tablo 1'in verilerine göre, kahvehaneye geliş nedenleri gösterilirken, ilk sırada \%47 (215 kişi) ile oyun oynamak (52, okey, tavla vb.) yer almaktadır. İkinci en yüksek oran ise, \%13,4 (61 kişi) ile gazete okumak olarak görülmektedir. Sohbet etmek, \%10,5 (48 kişi) oranı ile üçüncü sıraya yerleşmektedir.

Katılımcıların kahvehaneye geliş sıklığı; \%49,7 (227 kişi) ile haftada birkaç kez, \%25,6 (117 kişi) ile hafta sonları, \%19,3 (88 kişi) ile her gün, \%2,8 (13 kişi) ile ayda birkaç kez ve \%2,6 (12 kişi) ile nadiren şeklinde oranlanmıştır.

Evlerin kahvehaneye yakınlığına göre dağılım; \%45,7'si (209 kişi) yakın, \%26,5’i (121 kişi) ne yakın ne uzak, \%18,4'ü (84 kişi) çok yakın, \%8,5'i (39 kişi) uzak ve \%0,9'u (4 kişi) çok uzak şeklinde bir orana sahiptir.

Kahvehane alışkanlığının aile bireyleriyle iletişimlerini olumsuz yönde etkilemesi sorusuna verdikleri cevapların dağılımı; \%67 (306 kişi) hayır, \%22,5 (103 kişi) kısmen, \%10,3 (47 kişi) evet şeklindedir. Bu soruya cevap vermeyenler, \%0,2 (1 kişi) oranında kalmaktadır.

Kahvehanede en çok konuşulan alan, yine bir tablo ile gösterilmektedir (bkz. Tablo 2):

Tablo 2. Kahvehane Sohbetlerinde En Çok Konuşulan Alan

\begin{tabular}{|l|c|c|l|c|c|}
\hline En Çok Konuşulan Alan & $\mathbf{N}$ & $\mathbf{\%}$ & En Çok Konuşulan Alan & $\mathbf{N}$ & $\mathbf{\%}$ \\
\hline Siyaset & 108 & 23,6 & Cinsellik & 13 & 2,8 \\
\hline Futbol & 107 & 23,4 & Ekonomi & 13 & 2,8 \\
\hline Gündem & 93 & 20,4 & Edebiyat & 8 & 1,8 \\
\hline Dini konular & 47 & 10,3 & Magazin & 7 & 1,5 \\
\hline İş & 40 & 8,8 & Diğer & 6 & 1,3 \\
\hline Bilim & 15 & 3,3 & Toplam & $\mathbf{4 5 7}$ & $\mathbf{1 0 0 , 0}$ \\
\hline
\end{tabular}

Tablo 2'ye göre, kahvehane sohbetlerinde en çok konuşulan alanlar; ilk sırada \%23,6 (108 kişi) oranı ile siyaset, ikinci sırada \%23,4 (107 kişi) ile oranı ile futbol, üçüncü sırada \%20,4 (93 kişi) gündem olarak yansımaktadır.

Katılımcıların farklı siyasi görüşten kişilerle sohbet etme sıklığı ise; \%55,6 (254 kişi) ile ara sıra, \%35,9 (164 kişi) ile sürekli ve \%8,5 (39 kişi) ile hiçbir zaman şeklinde olarak oranlanmıştır.

Farklı siyasi görüşe sahip insanlarla sohbet edildiğinde; \%72,4 (331 kişi) oranında bazı zamanlar fikirlerinin değişebildiği yönünde cevap verilirken, \%26,5 (121 kişi) oranında ise fikirlerine hiçbir etkisi olmadığ 1 şeklinde cevap verilmiştir. \%1,1'lik kesim (5 kişi), bu soruyu cevapsız bırakmıştır.

Kahvehanede kitap, gazete, dergi vb. okunduğunda, en çok okuma yapılan alanın hangisi olduğuna yönelik sorgulamada aşağıdaki tablo ile karşılaşılmaktadır (bkz. Tablo 3): 
Tablo 3. Kahvehanede En Çok Okunan Alan

\begin{tabular}{|l|c|c|l|c|c|}
\hline En Çok Okunan Alan & $\mathbf{N}$ & $\mathbf{\%}$ & En Çok Okunan Alan & $\mathbf{N}$ & $\mathbf{\%}$ \\
\hline Siyaset & 180 & 39,4 & Diğer & 12 & 2,6 \\
\hline Gündem & 75 & 16,4 & Magazin & 10 & 2,2 \\
\hline Spor & 56 & 12,3 & Kültür-Sanat & 6 & 1,3 \\
\hline Ekonomi & 39 & 8,5 & Cevapsız & 27 & 5,9 \\
\hline Edebiyat & 27 & 5,9 & & & \\
\hline Bilim & 25 & 5,5 & Toplam & $\mathbf{4 5 7}$ & $\mathbf{1 0 0}$ \\
\hline
\end{tabular}

Tablo 3'e göre, en çok okuma yapılan içerik kategorisi; \%39,4 oranı (180 kişi) ile siyaset, $\% 16,4$ oranı (75 kişi) ile gündem, \%12,3 oran1 (56 kişi) ile spor şeklinde yansımıştır.

Katılımc1ların kahvehanede okudukları üzerine sohbet etmelerine göre dağ1lımı; \%52,3’ü (239 kişi) evet, \%26,3'ü (120 kişi) ara sıra ve \%19’u (87 kişi) hayır şeklinde gerçekleşmiştir. Katılımcıların \%2,4’ü (11 kişi) bu soruyu cevapsız bırakmıştır.

Kahvehanede radyo dinleme; \%44,4 (203 kişi) hayır, \%28,5 (130 kişi) ara sıra ve \%27,1 (124 kişi) evet şeklinde bir dağılıma sahip olmuştur.

Kahvehanede televizyon izleme oranları ise; \%59,7 (273 kişi) evet, \%28 (128 kişi) ara sıra ve \%12,3 (56 kişi) hayır şeklindedir.

Kahvehanede TV izlendiğinde, nelerin izlendiğini sorgulayan soruya katılımcılar şöyle yanıt vermiştir (bkz. Tablo 4):

Tablo 4. Kahvehanede TV'de En Çok İzlenen Programlar

\begin{tabular}{|l|c|c|l|c|c|}
\hline $\begin{array}{l}\text { En Çok İzlenen TV } \\
\text { Programları }\end{array}$ & N & \% & $\begin{array}{l}\text { En Çok İlenen TV } \\
\text { Programları }\end{array}$ & N & $\%$ \\
\hline Siyaset Programları & 120 & 26,3 & Evlilik Programları & 15 & 3,3 \\
\hline Haberler & 119 & 26,0 & Diğer & 8 & 1,8 \\
\hline Spor Programları & 107 & 23,4 & Cevapsız & 16 & 3,5 \\
\hline Sağıı Programları & 46 & 10,1 & & & \\
\hline Ekonomi Programları & 26 & 5,6 & Toplam & $\mathbf{4 5 7}$ & $\mathbf{1 0 0 , 0}$ \\
\hline
\end{tabular}

Tablo 4'e göre, kahvehanede en çok izlenen programlar; \%26,3 (120 kişi) ile siyaset programları, \%26 (119 kişi) ile haberler ve \%23,4 (107 kişi) ile spor programları olarak gerçekleşmektedir.

İzlenen programlar ile ilgili sohbet etmenin oranları ise; \%58,9 (269 kişi) evet, \%29,1 (133 kişi) ara sıra ve \%9,8 (45 kişi) hayır şeklindedir. Bu soruyu cevapsız bırakanların oranı, $\% 2,2$ (10 kişi) düzeyinde olmaktadır.

Aktif olarak kullanılan sosyal medya (Facebook, Periscope, Twitter vb.) hesabı olma sorusuna verilen cevapların dağılımı; \%56,2 (257 kiși) evet ve \%43,8 (200 kiși) hayır șeklinde olmaktadır.

Sosyal medyada gündeme gelen konuların kahvehane sohbetlerinde konuşulma oranları; \%47,9 (219 kişi) hayır, \%28 (128 kişi) evet ve \%23,9 (109 kişi) ara sıra olarak yansımaktadır. Sorunun cevapsız bırakılma oranı, \%0,2 (1 kişi) düzeyindedir.

Katılımcıların kahvehane ortamının sosyal niteliğine ve psikolojik etkilerine dönük algılamaları şöyle yansımıştır (bkz. Tablo 5): 
Tablo 5. Katılımcıların Kahvehanelerin Sosyal Niteliğine Yönelik Algıları

\begin{tabular}{|c|c|c|c|c|c|}
\hline $\begin{array}{l}\text { Kahvehanelerin Sosyal Nitelikleri ve Psikolojik Etkilerine } \\
\text { Yönelik Yargılar }\end{array}$ & $\mathbf{N}$ & Min. & Mak. & A.O. & $\begin{array}{l}\text { Std. } \\
\text { Sapma }\end{array}$ \\
\hline $\begin{array}{l}\text { Kahvehanelerde insanların sohbet ederek rahatladıklarını } \\
\text { gözlemliyorum. }\end{array}$ & 452 & 1,00 & 5,00 & 3,74 & 1,22 \\
\hline $\begin{array}{l}\text { Kahvehanelerdeki sohbet ortamının toplumsal gündem } \\
\text { konularına yönelik kanaatleri etkilediğini gözlemliyorum. }\end{array}$ & 457 & 1,00 & 5,00 & 3,73 & 1,30 \\
\hline $\begin{array}{l}\text { Kahvehanelerdeki tartışmaların eleştirel bir nitelik taşıdığını } \\
\text { düşünüyorum. }\end{array}$ & 451 & 1,00 & 5,00 & 3,62 & 1,10 \\
\hline $\begin{array}{l}\text { Kahvehanelerdeki sohbetlerde kanaat önderlerinin önemli bir } \\
\text { rolü olduğunu düşünüyorum. }\end{array}$ & 457 & 1,00 & 5,00 & 3,60 & 1,30 \\
\hline $\begin{array}{l}\text { Kahvehanelerde tartişılan siyasal söylemlerin belirli bir } \\
\text { statükoya hizmet eden görüşler olduğunu düşünüyorum. }\end{array}$ & 456 & 1,00 & 5,00 & 3,53 & 1,27 \\
\hline $\begin{array}{l}\text { Kahvehanelerin önemli toplumsal iletişim merkezleri olduğunu } \\
\text { düşünüyorum. }\end{array}$ & 457 & 1,00 & 5,00 & 3,52 & 1,26 \\
\hline $\begin{array}{l}\text { Kahvehaneler insanların kendilerini ifade edebildikleri sosyal } \\
\text { mekânlardır. }\end{array}$ & 457 & 1,00 & 5,00 & 3,50 & 1,25 \\
\hline $\begin{array}{l}\text { Kahvehanelerdeki sohbetlerde toplumun örf ve adetlerine } \\
\text { uygun bir üslupta tartışma yapıldığını gözlemliyorum. }\end{array}$ & 456 & 1,00 & 5,00 & 3,48 & 1,40 \\
\hline $\begin{array}{l}\text { Kahvehanelerdeki dini konulu tartışmaların bilgilendirici } \\
\text { olduğunu düşünüyorum. }\end{array}$ & 457 & 1,00 & 5,00 & 3,24 & 1,31 \\
\hline $\begin{array}{l}\text { Kahvehane sohbetlerinde siyasal konuların iyi analiz edildiğini } \\
\text { düşünüyorum. }\end{array}$ & 454 & 1,00 & 5,00 & 3,17 & 1,20 \\
\hline $\begin{array}{l}\begin{array}{l}\text { Kahvehanelerin insanları aylak hale dönüştürdüğünü } \\
\text { düşünüyorum. }\end{array} \\
\end{array}$ & 457 & 1,00 & 5,00 & 3,14 & 1,42 \\
\hline $\begin{array}{l}\text { Kahvehanelerdeki siyasi tartışmaların insanların demokratik } \\
\text { tartışma kültürüne katkı sağladığını gözlemliyorum. }\end{array}$ & 457 & 1,00 & 5,00 & 3,13 & 1,21 \\
\hline $\begin{array}{l}\text { Kahvehanelerin insanları topluma duyarlı bireyler haline } \\
\text { getirdiğini düşünüyorum. }\end{array}$ & 457 & 1,00 & 5,00 & 3,09 & 1,35 \\
\hline $\begin{array}{l}\text { Kahvehanelerin insanların boş zamanlarını boşa harcadıkları } \\
\text { toplumsal mekânlar olduğunu düşünüyorum. }\end{array}$ & 457 & 1,00 & 5,00 & 3,09 & 1,39 \\
\hline $\begin{array}{l}\text { Kahvehanelerdeki siyasi tartşmaların bilgi düzeyi açısından } \\
\text { düşük düzeyli olduğunu gözlemliyorum. }\end{array}$ & 457 & 1,00 & 5,00 & 3,08 & 1,35 \\
\hline $\begin{array}{l}\text { Kahvehanelerin yaşam tecrübesi yönünden eğitici olduğunu } \\
\text { düşünüyorum. }\end{array}$ & 453 & 1,00 & 5,00 & 3,00 & 1,25 \\
\hline $\begin{array}{l}\text { Kahvehanelerdeki güncel siyasete yönelik tartışmalarda tarihi } \\
\text { gerçeklerin analiz edildiğini gözlemliyorum. }\end{array}$ & 457 & 1,00 & 5,00 & 2,86 & 1,32 \\
\hline $\begin{array}{l}\text { Kahvehanelerde edebiyat (şiir, roman, hikâye vb.) üzerine } \\
\text { tartışmalar yapıldığını gözlemliyorum. }\end{array}$ & 457 & 1,00 & 5,00 & 2,48 & 1,28 \\
\hline
\end{tabular}

Tablo 5'in verilerine göre, katılımcılar, kahvehane sohbetlerinin rahatlatıcı etkisi olduğunu (A.O. $=3,74)$ oranı ile düşünmektedirler. Kahvehanelerdeki sohbet ortamının toplumsal gündem konularına yönelik kanaatleri etkilediğini (A.O.=3,73) düzeyinde ifade etmişlerdir. Kahvehanelerdeki tartışmaların eleştirel bir nitelik taşıdığı, (A.O.=3,62) oranı ile düşünülmektedir. Bunlar, katılımcıların en yüksek düzeyde katıldıkları yargılardır. En düşük düzeyde katılım gösterilen yargılara da yer vermek gerekirse, kahvehanelerde güncel siyasete yönelik tartışmalarda tarihi gerçeklerin analiz edildiği $($ A.O. $=2,86)$ oranı ile algılanmaktadır. Kahvehanelerde edebiyat (şiir, roman, hikâye vb.) üzerine tartışmaların yapıldığı yönündeki görüşler, (A.O.=2,48) düzeyinde yine düşük düzeyde bir katılım ile aktarılmıştır. 
Tablo 6. Katılımcıların Kendi Deneyimlerine İlişkin Görüşleri

\begin{tabular}{|l|c|c|c|c|c|}
\hline Bireysel deneyimlere ilişkin yargılar & N & Min & Mak. & A.O. & $\begin{array}{c}\text { Std. } \\
\text { Sapma }\end{array}$ \\
\hline Kahvehanede samimi bir arkadaşlık ortamına sahibim. & 457 & 1,00 & 5,00 & 3,67 & 1,20 \\
\hline Kahvehanede iyi bir iletişim ortamına sahibim. & 457 & 1,00 & 5,00 & 3,65 & 1,35 \\
\hline $\begin{array}{l}\text { Kahvehanede Gaziantep'teki gelişmeler üzerine geniş } \\
\text { bir bilgi birikimine sahip oluyorum. }\end{array}$ & 456 & 1,00 & 5,00 & 3,44 & 1,15 \\
\hline $\begin{array}{l}\text { Kahvehanede Türkiye'deki gelişmeler üzerine geniş bir } \\
\text { bilgi birikimine sahip oluyorum. }\end{array}$ & 457 & 1,00 & 5,00 & 3,36 & 1,19 \\
\hline $\begin{array}{l}\text { Kahvehanedeki arkadaşlarımla siyasi konular üzerine } \\
\text { demokmatik bir şekilde tartı̧̧ma firsatını ediniyorum. }\end{array}$ & 457 & 1,00 & 5,00 & 3,11 & 1,19 \\
\hline $\begin{array}{l}\text { Kahvehanede insanların sosyal statüsüne bakmadan } \\
\text { sohbet ederim. }\end{array}$ & 455 & 1,00 & 5,00 & 3,10 & 1,45 \\
\hline $\begin{array}{l}\text { Kahvehanede dünyadaki gelişmeler üzerine geniş bir } \\
\text { bilgi birikimine sahip oluyorum. }\end{array}$ & 456 & 1,00 & 5,00 & 2,63 & 1,22 \\
\hline
\end{tabular}

Tablo 6'daki verilere göre, bu kamusal alanlarda samimi arkadaşlık ortamına sahip olunduğu, $($ A.O. $=3,67)$ oranında savunulmaktadır. Yine kahvehanede iyi bir iletişim ortamına sahip olma, $(\mathrm{A} . \mathrm{O}=3,65)$ ortalamanın üzerinde bir düzeyde hissedilmektedir. Burada yapılan sohbetlerin dünyadaki gelişmeler üzerine geniş bir bilgi birikimi sağladığ 1 , (A.O. $=2,63)$ oranı ile düşük oranda düşünülmektedir.

Sosyo-demografik değişkenler ile çeşitli yargılar arasındaki ilişkiye dönük ANOVA testi sonuçları da araştırmaya katkı sağlayacaktır. Bu nedenle yapılan birkaç sorgulama aşağıdaki gibi yansımaktadır:

Katılımcıların sorulara verdikleri cevaplarda, yaş ile boş zamanları boşa harcama düşüncesi arasında anlamlı bir farklılık bulunmaktadır $(\mathrm{F}=2,80, \mathrm{p}=, 011)$. 18-25 yaş arası katılımcılar bu yargıya $(\mathrm{A} . \mathrm{O} .=3,27)$ oranında katılırken, $34-41$ yaş arası katılımcılar $(\mathrm{A} . \mathrm{O}=2,94)$ oranında katılmaktadırlar.

Meslek ile kahvehanelerin önemli toplumsal iletişim merkezleri olduğu yönündeki cevaplar arasında anlamlı bir fark ortaya çıkmaktadır $(\mathrm{F}=2,63 \mathrm{p}=, 023)$. Buna göre, esnaflar (A.O. $=3,62)$ ortalama ile bu görüşe katılırken, işsizler $(\mathrm{A} . \mathrm{O}=2,89)$ ortalama ile katılmaktadırlar.

Memleket ile kahvehanelerdeki sohbetlerde toplumun örf ve adetlerine uygun bir üslupta tartışma yapılması arasında anlamlı bir farklılık vardır $(\mathrm{F}=3,41, \mathrm{p}=, 001)$. Buna göre, Adanalılar bu yargıya (A.O. $=3,00)$ oranında katılırken, Adıyamanlılar ise (A.O. $=3,92)$ oranında katılmaktadırlar.

Yaş ile kahvehanede iyi bir iletişim ortamına sahip olma yargısı arasında anlamlı bir farklı1ık görünmektedir $(\mathrm{F}=3,99 \mathrm{p}=, 001) .18-25$ yaş arasındaki katılımcılar $(\mathrm{A} . \mathrm{O}=3,00)$ oranı ile katılırken, 42-49 yaş arasındakiler (A.O. $=3,61)$ oranında katılmaktadırlar.

Eğitim düzeyi ile kahvehanedeki arkadaşlarla siyasi konular üzerine demokratik bir şekilde tartışma firsatı edinme düşüncesi arasında anlamlı bir fark bulunmamaktadır $(\mathrm{F}=, 361$ $\mathrm{p}=$,697). Bu yargı için yapılan sorgulamada; lise düzeyindeki katılımcılar (A.O. $=3,20$ ), okuryazarlık düzeyindeki katılımcılar $(\mathrm{A} . \mathrm{O}=3,11)$ ve ilkokul/ilköğretim düzeyindeki katılımcılar (A.O. $=3,06)$ oranına sahiptirler.

\subsection{Bulguların Yorumu}

Gaziantep kent merkezinde yapılan araştırma verileri değerlendirildiğinde; kahvehaneler, sadece erkeklerin tercih ettiği; daha çok orta yaş grubunda yoğunlaşma olduğu; evli ve çocuk sahibi erkeklerin ağırlıkla bu mekânlara yöneldiği; meslek yönünden esnaf, işçi ve emeklilerin tercih ettiği; Türkiye standartlarında orta sınıf denebilecek bireylerin uğradığı; eğitim düzeyi 
yüksek olmayan kişilerin daha çok rağbet gösterdiği; Gaziantep ve çevre illerden gelen ailelere mensup kişilerin vakit geçirdikleri mekânlardır (bkz. sosyo-demografik değişkenlere ait veriler).

Bireylerin kahvehaneye geliş nedenlerinde oyun oynamak başat rolü üstlenirken; gazete okumak ve sohbet etmek de önemli nedenler arasında gösterilebilmektedir (bkz. Tablo 1). Buradaki sonuçlar, kahvehanelerin önemli iletişim merkezleri olduğu yönündeki bilgileri destekleyici niteliktedir.

Kahvehaneler, müdavimlerinin sık denebilecek yoğunlukta uğradıkları mekânlar olarak dikkat çekmektedir. Aynı zamanda kahvehane müdavimleri genellikle evlerine yakın muhitlerdeki kahvehanelere gitmektedirler. Katılımcılar, kahvehane alışkanlığının çok fazla aile meselesi haline getirilmediğini belirtmektedirler.

Kahvehanelerde en yoğun konuşulan kategorilere bakıldığında; siyaset, futbol ve gündemin öne çıktığı; dini konular üzerine tartışmaların da yapıldığı görülmektedir (bkz. Tablo 2). Buna göre, kahvehanelerin sosyal konular üzerine tartışmak açısından zengin bir yapıya sahip olduğu düşünülebilir. Kahvehanelerde farklı siyasal görüşten kişilerle sohbet etmeye açık bir yapı olduğu ve bu görüşmelerde bazen fikir değişikliklerinin yaşanabileceği anlaşılmaktadır. $\mathrm{Bu}$ veriler, kahvehanelerin kamusallığa açık bir yapıya sahip olduğunu düşündürmektedir.

Kahvehanede okuma yapıldığında, konu olarak siyasetin yoğun düzeyde, gündem ve spor kategorilerinin de önemli sayılabilecek ölçüde ilgi çektiği görülmektedir (bkz. Tablo 3). $\mathrm{Bu}$ veriler, tartışma ortamındaki ilgilenimler ile aynı yönelimdedir. Nitekim okunan şeyler ile ilgili genellikle sohbet edildiği sonucuna ulaşılmaktadır. Kahvehanede radyo dinlemeye kıyasla televizyon izleme alışkanlığının rağbette olduğu anlaşılmaktadır. Kahvehanede televizyon izlerken, en yoğun düzeyde siyaset programları, haberler ve spor programlarının takip edildiği bilgisi ortaya çıkmaktadır. Kahvehane müdavimleri, izledikleri programlar üzerine de sohbet etme ve tartışma eğilimine de yönelmektedirler.

Kahvehane müdavimlerinin çoğunluğu sosyal medya kullanıcıları olarak görünse de, sosyal medyada öne çıkan konuları kahvehane ortamında aynı yoğunlukta tartışmamaktadırlar.

Kahvehanelerin sosyal niteliklerine ve psikolojik etkilerine bakıldığında; kahvehane müdavimlerinin kendilerini bu mekânlarda rahatlamış hissettiklerini; kahvehanelerde gündeme ilişkin kanaatlerin etkilendiği; kahvehane tartışmalarının eleştirel bir yapıda olduğu; kahvehanelerdekanaatönderlerinin önemli roller üstlendiği; kahvehanelerdeki siyasal söylemlerin belirli bir statükodan yana üretildiği; kahvehanelerin önemli sosyal iletişim mekanizmaları olduğu; kahvehane ortamında bireylerin kendilerini en iyi şekilde ifade edebildikleri sonucu ortaya çıkmaktadır. Kahvehane ortamında güncel siyasete ilişkin tartışmalarda tarihi gerçekliklerin analiz edilmesine; edebi eserler üzerine tartışmalar yapılmasına sık rastlanmadığı da açığa çıkmaktadır (bkz. Tablo 5).

İnsanlar, kahvehane ortamında samimi arkadaşlıklar kurmakta; yaşadığı şehir ve ülke hakkında bilgi edinmektedir. Bununla birlikte dünyadaki gelişmeleri sık takip etmemektedir (bkz. Tablo 6). Buradan kahvehanelerin daha çok yerel bilgi kaynakları olduğu yönünde bir çıkarım yapılabilir.

Sosyo-demografik değişkenler ile çeşitli yargılar arasında bir bağıntı kurulduğunda, şöyle bir tablo ortaya çıkmaktadır: Kahvehane müdavimleri arasında genç kesim orta yaş aralığındaki bir kesime görece kahvehanelerde vakit geçirmeyi boş zaman kaybı olarak değerlendirmektedir. Esnaf kesimi, işçi kesim ile kıyaslandığında, kahvehaneyi belirgin bir yönelimde önemli toplumsal iletişim merkezi olarak algılamaktadır. Adıyaman kökenli kahvehane müdavimleri, Adana kökenlilerden daha çok kahvehane sohbetlerinin toplumun örf ve adetleriyle örtüşen bir üslupta gerçekleştiğini düşünmektedir. Yine yaş üzerinden bir sorgulama yapıldığında, orta yaş civarından bir kesim kahvehanede oldukça iyi bir iletişim ortamına sahip olduğunu düşünürken, genç kesimin bu yöndeki düşüncesi daha muğlaktır. Eğitim düzeyi, siyasi konularda demokratik tartışma için bir ayırıcı kriter olarak görülmemektedir (bkz. ANOVA testi verileri). 


\section{Sonuc}

Kahvehane müessesesi, ortaya çıktığ 1 16. yüzyıldan günümüze kadar Anadolu topraklarında önemli işlevler üstlenen sosyal iletişim mekanizmaları olarak kabul edilebilir. Kahvehanenin halen önemli olduğu gerçeği, bu mekânlara rağbetin yoğun olması neticesinden anlaşılabilir.

Kahvehaneler, Türk toplumunda erkeklerin özellikle de muhitlerine yakın yerlerde uğradıkları; oyun oynayarak ve sohbet ederek stres attıkları; kimi zaman siyaset, gündem üzerine konuşarak kanaat edindikleri ve fikir paylaşımında bulundukları sosyal mekânlar olma özelliğini taşımaktadır.

Araştırma sonuçlarına göre, kahvehanelerde insanların boş vakitlerini amaçsız bir şekilde tükettikleri belirgin değildir. Üstelik siyasete yönelik demokratik tartışma ortamının daha yüksek düzeyde ortaya çıkışı, kahvehane tartışmalarının eleştirel nitelik taşımasının yüksek bir oranda kabul görmesi, günümüzde dahi önemli kamusal iletişim merkezleri olduğu görüşünü destekleyici bir nitelik taşımaktadır.

Kahvehanelerde gazete okuma alışkanlığının yer etmesi, geçmişteki kıraathane kültürünün etkisinin devamı olarak yorumlanabilir. Kahvehane ortamında insanların pek çok alanda bilgilendiği gerçeği, araştırmanın bir diğer önemli sonucudur. Buna göre, kahvehane müdavimleri bu sosyal etkileşim ortamlarına salt oyun oynama amaciyla gelmemekte; bunun yanı sıra özellikle yerel konularda bilgilenmekte, siyasal tartışmalara yönelmektedir. Böylece kahvehanelerin sosyal açıdan çok işlevli oldukları kanısına varılabilir.

Sosyal iletişim kurumları olarak kahvehaneler üzerine çalışma yapacak olan araştırmacılar için bu çalışma önemli nicel veriler içermektedir. Bu konuda çalışacak araştırmacılara kahvehane ortamında gözlemler yapmaları, kahvehane müdavimleri ile derinlemesine görüşmeler yoluyla nitel araştırmalara yönelmeleri önerilmekte; böylece iletişim sosyolojisi açısından literatüre önemli katkılar yapılacağı düşünülmektedir. 


\section{Kaynakça}

Abasıyanık, S. F. (2005). Mahalle Kahvesi. İstanbul: Yap1 Kredi Yayınları.

Aydın, C. (2011). Kahvehanelerin Kültürel Yaşamdaki Rolü. K. Kahraman, (Ed.). Tüm Zamanların Hattrina Sarayda Bir Fincan Kahve (s. 81-89). İstanbul: TBMM Milli Saraylar Daire Başkanlığı Yayını.

Berkes, N. (2012). Türkiye'de Çağdaşlaşma. İstanbul: Yapı Kredi Yayınları.

Birsel, S. (2014). Kahvehaneler Kitabı. İstanbul: Sel Yayıncılık.

Çağlayan, S. (2012). Anadolu'nun İlk Kamusal Mekânı: Kahvehane. Muğla Sıtkı Kocaman Üniversitesi Sosyal Bilimler Enstitüsü Dergisi, (29), 95-110.

Demiray, G. (2011). Sufi Meclislerinden Kahvehanelere. K. Kahraman (Ed.). Tüm Zamanların Hatırına Sarayda Bir Fincan Kahve (s. 65-79). İstanbul: TBMM Milli Saraylar Daire Başkanlığı Yayını.

Deniş, H. E. (2011). Osmanlı ve Cumhuriyet Döneminde Kahvehaneler: Sosyal ve Siyasal Yaşamın İncelenmesi. Akademik Bakış Dergisi, (27), 1-16.

Ediz, İ. (2008). Osmanlı'dan Cumhuriyet'in İlk Yıllarına Kahvehaneler ve Sosyal Değişim. Sakarya Üniversitesi Fen Edebiyat Dergisi, 10 (8), 179-189.

Göktaş, E. (1999). Osmanlı Döneminde Kahvehaneler, Kıraathaneler ve Bunların İşlevleri. Türkiyat Araştırmaları Enstitüsü Dergisi, (11), 67-80.

Habermas, J. (2009). Kamusallı̆̆ı Yapısal Dönüşümü. (T. Bora ve M. Sancar, Çev.). İstanbul: İletişim Yayınları.

Hattox, R. S. (1998). Kahve ve Kahvehaneler. (N. Elhüseyni, Çev.). İstanbul: Tarih Vakfı Yu rt Yayınları.

Heise, U. (2001). Kahve ve Kahvehane. (M. Tüzel, Çev.). Ankara: Dost Kitabevi.

Kazanc1, M. (2006). Osmanlı'da Halkla İlişkiler. Selçuk İletişim, 4 (3), 5-20.

Koçu, R. E. (2003). Tarihimizde Garip Vakalar. İstanbul: Doğan Kitapçılık.

Koz, G. F. (2011). Çekirdekten Fincana: Bir Yudum Kahve Kırk Yıl Hatır. K. Kahraman (Ed.), Tüm Zamanların Hatırına Sarayda Bir Fincan Kahve (s.13-35). İstanbul: TBMM Milli Saraylar Daire Başkanlığı Yayını.

Kuş, E. (2009). Nicel-Nitel Araştırma Teknikleri. Ankara: Anı Yayıncılık.

Kuzucu, K. Ve Koz, M. S. (2015). Türk Kahvesi. İstanbul: Yapı Kredi Yayınları

Lewis, B. (1975). İstanbul ve Osmanlı Uygarlı̆̆ı. (N. Önol, Çev.). İstanbul: Varlık Yayınevi.

Nazır, B. (2011). Dersaadet'te Ticaret. İstanbul: İstanbul Ticaret Odası Yayınları.

Okumuş, E. (2013). Odunpazarı Evlerinde Ramazan Gecelerinde Boş Zaman Mekânları.

Eskişehir Osmangazi Üniversitesi Sosyal Bilimler Dergisi, 4 (Özel Say1), 103-140.

Öztürk, S. (2005). Osmanlı İmparatorluğunda Kamusal Alanın Dinamikleri. Gazi

Üniversitesi Illetişim Fakültesi Yayını, 21, 95-124.

Öztürk, S. (2006). Cumhuriyet Türkiyesinde Kahvehane ve İktidar (1930-1945). İstanbul:

Kırmızı Yayınları. 
Öztürk, S. (2010). Osmanlı'da Illetişsimin Diyalektiği. Ankara: Phoenix Yayınevi.

Pamuk, O. (2013). İstanbul -Hatıralar ve Şehir. İstanbul: Yapı Kredi Yayınları.

Sami, K. (2010). Halk Kültürü Bağlamında Kahvehanelerin Toplumsal ve Mekânsal Dönüşümleri Diyarbakır Kent Örneği. Milli Folklor, 22 (85), 159-172.

Standage, T. (2016). Altı Bardakta Dünya Tarihi. (A. Fehmi, Çev.). İstanbul: Kırmızı Kedi Yayınevi.

Şahbaz, S. (2007). Geçmişten Günümüze Kahvehaneler, Kahvehanelerin Sosyal Yaşamdaki Yeri ve Önemi: Aydın Merkez Örneği. Yayımlanmamış Yüksek Lisans Tezi, Adnan Menderes Üniversitesi, Aydın.

TDK (Türk Dil Kurumu ). (2016) Sözcük arama: kahve. Erișim Tarihi: 16 Haziran 2016 http://www.tdk.gov.tr/index.php?option=com_gts\&arama=gts\&guid=TDK. GTS.578827b6667438.03787734

Tez, Z. (2015). Lezzetin Tarihi. İstanbul: Hayykitap.

Tunç, Ş. (2014). Osmanlı Payitahtında Kahvehane ve Kahvehane Kültürünün Yeri. Yayımlanmamış Yüksek Lisans Tezi, İstanbul Üniversitesi, İstanbul.

Tutal, O. (2014). Kırk Y1llık Hatırın İletişim Mekânı Olarak Kahvehaneler. Anadolu Üniversitesi Sosyal Bilimler Dergisi, 12 (3), 151-166.

Ulusoy, K. (2011). Türk Toplum Hayatında Yaşatılan Kahve ve Kahvehane Kültürü. Milli Folklor, 23 (89), 159-169.

Ürer, H. (2010). Osmanlı'da Kahve/kahvehane Kültürü ve Salihli’den Bir Kahvehane Örneği "Himaye-i Etfal". Sanat Tarihi Dergisi, 19 (2), 1-26.

Yağbasan, M. ve Ustakara, F. (2008). Türk Toplumunda Kahvehane ve Kafelerdeki İletişimsel Ortamı Belirlemeye Yönelik Bir Alan Araştırması (Gaziantep İli Örneği). Firat Üniversitesi Sosyal Bilimler Dergisi, 18 (1), 233-260.

Yaşar, A. (2010). Osmanlı' da Kamu Mekânı Üzerine Mücadele: Kahvehane Yasaklamaları. XV. Türk Tarih Kongresi. (s. 1403-1410), Ankara: Türk Tarih Kurumu Basımevi.

Film ve Dizi Kaynakçası

Alp, M. Y., (Yapımc1), Aydemir, S., Kaman, M. Ve Kaman, E. (Senarist), Aydemir, S. (Yönetmen). (2014). Kardeş Payl [Dizi]. Türkiye: NTC Yapım.

Barkan, O. ve Ataman, N. (Yapımc1), Șendil, S. (Senarist), Eğilmez, E. (Yönetmen). (1973). Canım Kardeşim [Film]. Türkiye: Arzu Film.

Erman, H. (Yapımc1), Bugay, U. (Senarist), Alasya, Z. (Yönetmen). (1977). Aslan Bacanak [Film]. Türkiye: Erman Film.

Kılıç, Y. (Yapımc1), Baytan, N. (Senarist), Baytan, N. (Yönetmen). (1981). Üç Kâğıtçı [Film]. Türkiye: Cumhur Film.

Kılıç, Y. (Yapımc1), Üstel, A. (Senarist), Baytan, N. (Yönetmen). (1982). Yedi Bela Hüsnü [Film]. Türkiye: Cumhur Film.

Sınav, O. ve Şaşmaz R. (Yapımc1), Özdener, B., Kaçan, H., Turgut, M., Şaşmaz, R. Ve 
Aktuğ, E. (Senarist), Kaçan, H., Ateş, G., Günay, M. Ve Ekiz, E. (Yönetmen). (2002). Ekmek Teknesi [Dizi]. Türkiye: Sinegraf Ltd. ve Pana Film.

Sunal, K. ve Girik, F. (Yapımc1), Seden, O. F. (Senarist), Seden, O. F. (Yönetmen). (1978). Yüz Numaralı Adam [Film]. Türkiye: Can Film.

Ün, M. (Yapımc1), Tekiner, S.; Yurdakul, R.; Oran, B. (Senarist), Tibet, K. (Yönetmen). (1979). Umudumuz Şaban [Film]. Türkiye: Uğur Film.

Ün, M. (Yapımc1), Seden, O. F. (Senarist), Tibet, K. (Yönetmen). (1984). Orta Direk Şaban [Film]. Türkiye: Uğur Film. 